\title{
Sorption of Heavy Metal Ions from Aqueous Solutions: A Review
}

\author{
Guixia Zhao, Xilin Wu, Xiaoli Tan and Xiangke Wang* \\ Key Laboratory of Novel Thin Film Solar Cells, Institute of Plasma Physics, Chinese Academy of Sciences, \\ P.O. Box 1126, Hefei, 230031, P.R. China
}

\begin{abstract}
Sorption techniques are widely used to remove heavy metal ions from large volumes of aqueous solutions. Herein, the natural and some artificial materials, such as clay minerals, biosorbents, carbon-nanomaterials, metal oxides, are reviewed as adsorbents in the removal of different heavy metal ions, such as $\mathrm{Ni}(\mathrm{II}), \mathrm{Cu}(\mathrm{II}), \mathrm{Pb}(\mathrm{II}), \mathrm{Cd}(\mathrm{II}), \mathrm{Cs}(\mathrm{I})$, $\mathrm{Eu}(\mathrm{III}), \mathrm{Th}(\mathrm{IV}), \mathrm{Cr}(\mathrm{VI})$ from large volumes of aqueous solutions. The sorption kinetics and thermodynamics, the influence of environmental factors on the sorption, the possible sorption mechanism of heavy metal ions and the modification of adsorbents on the removal of heavy metal ions are discussed in detail. The sorption properties of the different adsorbents are also described. The different methods such as batch sorption techniques and spectroscopy techniques (such as XPS, FTIR, EXAFS, ATR-IR) in the determination of heavy metal ion sorption properties and sorption mechanisms are presented. Different models for the simulation of sorption isotherms and kinetic sorption data are given as a comparison to understand the sorption mechanism. Many amphibolous matters for further research and the necessity in the study of the selective adsorbents in multi-component sorption systems are also summarized.
\end{abstract}

Keywords: Metal ions, Sorption, Models, Kinetic, Thermodynamic data.

\section{INTRODUCTION}

The transfer of substances from a mobile phase (liquid or gaseous) to a solid phase is a universal phenomenon among the mobility of substances in aqueous porous media and aquatic environments. Sorption properties of metal ions are crucial for the evaluation of metal ion behavior in the natural environment. First, various treatment techniques and processes have been used to remove the pollutants from contaminated water. Among all the approaches proposed, sorption is one of the most popular methods and is currently considered as an effective, efficient and economic method for wastewater purification. Second, the relationship between catalysis and sorption is considered as the most important domain of surface science. The prerequisite of heterogeneous catalysis to occur is sorption (usually chemical one) of molecules of the reacting substances on the inner or outer surface of the adsorbent or of the catalyst; then molecular dissociation of at least one or two reacting components, usually preceded by surface diffusion. Besides, catalysts combined with adsorbents owning high sorption capacity are important to achieve high catalytic activity. For example, $\mathrm{TiO}_{2}$ supported adsorbent provides higher specific surface area and facilitates more effective sorption sites than bare $\mathrm{TiO}_{2}[1,2]$. As a result, the degradation rates of organic pollutants are usually higher than that of bare $\mathrm{TiO}_{2}$. Bhattacharyya et al. [3] loaded $\mathrm{TiO}_{2}$ on three different kinds of porous adsorbents, mesoporous (MCM-41), microporous ( $\beta$-zeolite) and pillared structure (montmorillonite) using sol-gel method, and the photocatalytic efficiency of the supported catalysts was evaluated

*Address correspondence to this author at the Key Laboratory of Novel Thin Film Solar Cells, Institute of Plasma Physics, Chinese Academy of Sciences, P.O. Box 1126, Hefei, 230031, P.R. China; Tel: 86-551-5592788; Fax: 86-551-5591310; E-mail: xkwang @ipp.ac.cn. using Orange II as model compound in water under different operating conditions. It was found that these three supported composite catalysts were more effective than bare $\mathrm{TiO}_{2}$ in photodegradation of Orange II. Machado et al. [4] obtained similar results by dispersing $\mathrm{TiO}_{2}$ on the surface of high surface area vermiculite to prepare composite adsorbent/catalyst for the decomposition of reactive textile dye, namely, Drimaren Red. What s more, combining the oxidation and reduction effect in sorption processes, some redox composite adsorbents have been developed and applied in water purification recently $[5,6]$.

Most of heavy metal ions are toxic to living organisms. These metal ions are non-degradable and are persistent in the environment. Therefore, the elimination of heavy metal ions from wastewater is important to protect public health. Sorption is considered as a very effective and economical process for metal ion removal from wastewaters. Up to now, plenty of research work has been focused on the sorption kinetics and thermodynamics, the factors influencing sorption properties, the possible sorption mechanisms and the modification of the adsorbents. In this review, we summarized the sorption kinetics and thermodynamics, sorption isotherm models, some mechanisms of metal ion sorption on different kinds of adsorbents used in the recent studies, and further research trend is also discussed.

\section{KIND OF ADSORBENTS}

\subsection{Clay Minerals}

Clay minerals have high sorption, ion exchange and expansion properties. They are widely used to adsorb all kinds of pollutants from large volumes of aqueous solutions. A lot of studies are focused on sorption of heavy metal ions on clay minerals. The sorption behaviors of $\mathrm{Hg}$ (II) on laterite 
from Guizhou Province, China, were studied [7]. The interaction of $\mathrm{Cs}(\mathrm{I})$ with different soils and clays was studied by combining microscopic and macroscopic techniques [8,9]. Among different soils, the decrease of $\mathrm{K}_{\mathrm{d}}$ (distribution coefficient) of cesium, at all $\mathrm{pH}$ levels, followed the sequence of sandyloam > loam > clayloam > clay, indicating that the particle size fractions and especially the clay contents played predominant role on sorption of $\mathrm{Cs}(\mathrm{I})$ to soils [9]. Similarly, the kinetics of $\mathrm{Ce}(\mathrm{III})$ sorption-desorption on four soils were also investigated by using batch technique with radionuclide ${ }^{141} \mathrm{Ce}$ as radiotracer [10]. Abollino et al. [11] studied the sorption of metal ions of $\mathrm{Cd}, \mathrm{Cr}, \mathrm{Cu}, \mathrm{Mn}, \mathrm{Ni}, \mathrm{Pb}$ and $\mathrm{Zn}$ on Na-montmorillonite, and found that Na-montmorillonite was a good adsorbent towards all examined metal ions. Calcium sorption on hydroxyapatite in aqueous solutions was studied [12], and the experimental data were analyzed by assuming a reversible component of the partition coefficient and a nonreversible sorption component that might result from the polycrystalline nature of the hydroxyapatite particle. AlDegs et al. [13] found that natural Jordanian clay containing silicate and carbonate minerals is an effective adsorbent for the removal of $\mathrm{Zn}(\mathrm{II}), \mathrm{Pb}$ (II), and $\mathrm{Co}(\mathrm{II})$ ions from aqueous solutions. Sorption of arsenite and arsenate to siderite, fougerite and magnetite was studied using batch sorption experiments and EXAFS spectroscopy technique, and the results showed that $\mathrm{As}(\mathrm{V})$ was adsorbed to fougerite, magnetite, and siderite by forming inner-sphere surface complexes, which were resulted from corner sharing between $\mathrm{AsO}_{4}$ groups and $\mathrm{FeO}_{6}$ octahedra and that $\mathrm{As}(\mathrm{III})$ also formed inner-sphere surface complexes on magnetite and fougerite but only a (presumably) weak outer-sphere complexes on siderite [14]. Experiments were conducted to quantify $\mathrm{Fe}(\mathrm{II})$ sorption onto goethite in the absence and presence of As(III). The experimental data obtained in single-sorbate experiments were modeled using a diffuse double layer surface complexation model and to compare sorption in dual-sorbate systems [15].

Except for researches on the natural minerals, many researches were focused on modified minerals. There have been various attempts to improve the quality and characteristics of the clays by modifying them with different techniques. In this regard, there are two of the common techniques, which are intercalation and pillaring, and acid activation. Unuabonah et al. [16] studied sorption of $\mathrm{Pb}$ (II) and $\mathrm{Cd}$ (II) from aqueous solutions onto sodium tetraboratemodified kaolinite clay, and an observed increase in the sorption capacity of the kaolinite after modification with sodium tetraborate corresponded to its increase in cation exchange capacity. Burch and Warburton [17] introduced Zrtetramers from fresh zirconyl chloride solution into montmorillonite. Other than $\mathrm{Zr}^{4+}$, the polycations, namely, $\mathrm{Al}^{3+}$, $\mathrm{Si}^{4+}, \mathrm{Ti}^{4+}, \mathrm{Fe}^{3+}, \mathrm{Cr}^{3+}$ or $\mathrm{Ga}^{3+}$ etc., have also been used as inorganic pillar. The removal of $\mathrm{Cd}^{2+}$ from aqueous solution by sorption using Fe-montmorillonite was studied by exchanging the original interlayer cations of montmorillonite by poly-hydroxyl ferric [18]. Compared to raw montmorillonite, the Fe-montmorillonite showed a much larger interlayer spacing, indicating a higher affinity for metal ions. Christidis et al. [19] also reported that treatment of bentonite with hydrochloric acid leaded to an increase of surface area as compared to the raw bentonite by as much as five times, and thereby enhanced the sorption capacity in the removal of heavy metal ions from aqueous solutions.

\subsection{Activated Carbon}

Activated carbons have high porosity, high surface area and are prepared from readily available carbonaceous precursors such as coal, wood, coconut shells and agricultural wastes. Activated carbons are extensively used in water treatment. These carbonaceous materials possess the potential for the removal of inorganic and organic pollutants from effluent streams. It was found that activated carbon possesses a significant weak acidic ion exchange character so as to remove trace metal contaminants and to adsorb pollutants from wastewater. In the work of Natale et al. [20], the sorption of pentavalent arsenic on a granular activated carbon (GAC) was experimentally studied. Activated carbon prepared from coconut tree sawdust was used as an adsorbent for the removal of $\mathrm{Cr}(\mathrm{VI})$ from aqueous solution [21]. Sorption and stability of mercury on activated carbon for emission control was investigated [22]. Powder activated carbon (PAC) prepared from Eucalyptus camaldulensis Dehn bark was tested for its sorption capacities $\left(\mathrm{q}_{\mathrm{m}}\right)$ at $60{ }^{\circ} \mathrm{C}$, where $\mathrm{q}_{\mathrm{m}}$ for $\mathrm{Cu}(\mathrm{II})$ and $\mathrm{Pb}(\mathrm{II})$ were calculated to be 0.85 and 0.89 $\mathrm{mmol} / \mathrm{g}$, respectively [23]. A novel sodium polyacrylate grafted activated carbon was produced by using gamma radiation to increase the number of functional groups on the surface, and this grafting technique could be applied to other adsorbents to increase the efficiency of metal ion sorption by activated carbon [24]. Activated carbons are suitable material in the removal of heavy metal ions because of there high sorption ability and low price.

\subsection{Carbon Nanotubes}

Recently, carbon nanotubes (CNTs), have attracted great interest due to their unique morphologies leading to potential applications. CNTs have enhanced surface sorption properties and were studied as media for the removal of different heavy metal ions from liquid phases. Li et al. [25-27] reported that oxidized CNTs showed exceptionally high sorption capacity and efficiency for $\mathrm{Pb}(\mathrm{II}), \mathrm{Cd}(\mathrm{II})$ and $\mathrm{Cr}(\mathrm{VI})$ from water. What s more, CNTs were found as good adsorbents for multi-component sorption of metal ions [28]. Gao et al. [29] investigated the factors affecting the sorption of transition metal ions on oxidized CNTs, and found that the sorption mechanisms were governed by the surface features, ion exchange process and electrochemical potential. The latter plays a significant role in multi-component sorption where redox reactions, not only on the adsorbent surface but also among the different adsorbates, are likely to occur. Wang et al. [30] used uncapped multiwall carbon nanotubes (MWCNTs) for ${ }^{243} \mathrm{Am}$ sorption from aqueous solution, and found that MWCNTs can adsorb ${ }^{243} \mathrm{Am}$ with extraordinarily high efficiency by forming very stable complexes. Oxidized MWCNTs were employed as adsorbent to study the sorption characteristic of $\mathrm{Pb}$ (II) from aqueous solution [31], and the results indicated that all the data of $\mathrm{C}_{\mathrm{eq}}$-q lied in a straight line with slope $\mathrm{V} / \mathrm{m}$ and intercept $\mathrm{C}_{0} \mathrm{~V} / \mathrm{m}$ for the same initial concentration of $\mathrm{Pb}(\mathrm{II})$ and the same content of oxidized MWCNTs for each experimental data. Oxidized MWCNTs were also applied to adsorb $\mathrm{Ni}(\mathrm{II})$ from aqueous solution 
[32], and the predominant mechanism of $\mathrm{Ni}(\mathrm{II})$ sorption onto MWCNTs was reported to be ion exchange at low $\mathrm{pH}$ values and by strong surface complexation at high $\mathrm{pH}$ values. The results of Th(IV) sorption on MWCNTs indicated that oxidized MWCNTs may be a promising material for the preconcentration and solidification of heavy metal ions [33]. By using chelating resin and XPS methods, Tan et al. [34] studied the sorption and kinetic desorption of ${ }^{152+154} \mathrm{Eu}$ (III) on MWCNTs, and found that MWCNTs were suitable material for preconcentration of lanthanides from large volumes of aqueous solutions in radioactive nuclear waste management with the strong surface complexation and/or chemisorption mechanism. With the aid of FITEQL 3.2, Chen et al. [35] characterized the surface properties of MWCNTs at different ionic strengths and $\mathrm{pH}$ values, and modeled $\mathrm{Sr}$ (II) and Eu (III) sorption onto oxidized MWCNTs by applying surface complexation model, and found that the diffuse layer model (DLM) fitted the experimental data very well. Rao et al. [36] studied the removal of divalent metal ions $\left(\mathrm{Cd}^{2+}\right.$, $\left.\mathrm{Cu}^{2+}, \mathrm{Ni}^{2+}, \mathrm{Pb}^{2+}, \mathrm{Zn}^{2+}\right)$ from aqueous solution using various kinds of CNTs, and suggested that CNTs are promising adsorbents for environmental protection application because of the superior sorption capacity and effective desorption of divalent metal ions. In future, CNTs can be produced in large scale such as chemical vapor deposition method, which is a promising route to reduce the cost of CNTs, and thereby increase the use of CNTs in environmental protection applications.

\subsection{Biosorbents}

Biosorption is a relatively new process that has proven very promising in the removal of contaminants from aqueous effluents using low-cost adsorbents derived from agricultural materials [37-42]. The major advantages of biosorption compared with conventional treatment methods are: lowcost, high efficiency, minimization of chemical and/or biological sludge, regeneration of biosorbent, no additional nutrient requirement, and possibility of metal recovery. Agricultural residues are lignocellulosic substances which contain three main structural components: hemicelluloses, cellulose and lignin. Guo et al. [43] investigated the sorption of the heavy metal ions $\mathrm{Pb}(\mathrm{II}), \mathrm{Cu}(\mathrm{II}), \mathrm{Zn}$ (II) and $\mathrm{Ni}(\mathrm{II})$ on a lignin isolated from black liquor, a waste product of the paper industry, and found that lignin had affinity with metal ions in the following order: $\mathrm{Pb}$ (II) $>\mathrm{Cu}$ (II) $>\mathrm{Cd}$ (II) $>\mathrm{Zn}$ (II) $>\mathrm{Ni}$ (II). Removal of $\mathrm{Cu}$ (II) from aqueous solution by different adsorbents such as shells of lentil (LS), wheat (WS) and rice (RS) was investigated. The maximum sorption capacities for $\mathrm{Cu}(\mathrm{II})$ on LS, WS and RS adsorbents at 293, 313, $333 \mathrm{~K}$ were found to be $8.977,9.510$ and $9.588 ; 7.391$, 16.077 and $17.422 ; 1.854,2.314$ and $2.954 \mathrm{mg} / \mathrm{g}$, respectively [44]. The sorption of Cd (II) from aqueous solution by rice husk, a surplus agricultural byproduct was investigated. Some simple and low-cost chemical modifications resulted in increasing of the sorption capacity of raw rice husk (RRH) from $8.58 \mathrm{mg} / \mathrm{g}$ to $11.12,20.24,16.18 \mathrm{mg} / \mathrm{g}$ and reducing the equilibrium time from $10 \mathrm{~h}$ of $\mathrm{RRH}$ to 2,4 and $1 \mathrm{~h}$ for epichlorohydrin treated rice husk (ERH), $\mathrm{NaOH}$ treated rice husk (NRH), sodium bicarbonate treated rice husk (NCRH), respectively [45]. Conrad et al. [46] did research on sorption of $\mathrm{Zn}(\mathrm{II})$ and $\mathrm{Pb}$ (II) on coir, and found that $\mathrm{Pb}$ (II) had a higher sorption affinity than Zn(II). In the review by Ngah et al. [47], an extensive list of plant wastes as adsorbents including rice husks, spent grain, sawdust, sugarcane bagasse, fruit wastes, weeds and others were compiled. Some of the treated adsorbents showed good sorption capacities for $\mathrm{Cd}, \mathrm{Cu}, \mathrm{Pb}, \mathrm{Zn}$ and $\mathrm{Ni}$. The interactions of metal ions with chitosan-based adsorbents were reviewed by Guibal et al. [48], and they concluded that metal ions can be adsorbed by chelation on amine groups of chitosan in near neutral solutions. These interactions of metal ions with chitosan can be used for decontamination of effluents, for the recovery of valuable metal ions but also for the development of new materials or new processes involving metal-loaded chitosan. Miretzky et al. [49] reviewed the recent developments in $\mathrm{Hg}$ (II) removal in wastewater treatment, using chitosan and its derivatives in order to provide useful information about the different technologies and reported the sorption capacity of chitosan and chitosan derivatives under different experimental conditions.

\subsection{Metal Oxides}

The main oxides used as adsorbents are Mn-oxides, Fe-oxides, $\mathrm{TiO}_{2}, \gamma-\mathrm{AlOOH}$, and $\gamma-\mathrm{Al}_{2} \mathrm{O}_{3}$ etc. Titanium oxide $\left(\mathrm{TiO}_{2}\right)$ has wide application and were investigated in solar energy conversion [50], photocatalyst [51], sensors [52], photochromic devices [53]. Debnath et al. [54] applied nanostructured hydrous titanium oxide (NHTO) to adsorb $\mathrm{Ni}(\mathrm{II})$ from natural and industrial wastewater, and found that the $\mathrm{Fe}(\mathrm{III})$ ion showed a strong negative influence on $\mathrm{Ni}(\mathrm{II})$ sorption to NHTO. The mean free energy of reaction indicated the columbic binding of the metal ion with the solid particles. Similarly, the sorption of $\mathrm{Se}$ (IV) on $\mathrm{TiO}_{2}$ (anatase) was investigated by Shi et al. [55]. The ART-IR spectroscopy analysis of the sorption of uranyl ions $\left(10^{-4} \mathrm{M}\right)$ onto titanium oxides (mixture of rutile and anatase) showed that uranyl sorption on titanium oxides in the $\mathrm{pH}$ range 4-7 was the formation of one surface complex where uranium ions had two different chemical environments [56]. Nano and Strathmann [57] used colloidal $\mathrm{TiO}_{2}, \gamma-\mathrm{AlOOH}$ and $\gamma-\mathrm{Al}_{2} \mathrm{O}_{3}$ as model hydrous oxides to investigate $\mathrm{Fe}$ (II) sorption to iron-free mineral surfaces, and found that iron-free soil minerals can exert a significant influence on $\mathrm{Fe}(\mathrm{II})$ sorption and speciation in heterogeneous aquatic systems. Reilly and Hochella [58] measured and compared $\mathrm{Pb}$ (II) sorption on a number of natural and synthetic $\mathrm{Mn}$ - and Fe-oxides using a flow-through reactor, and found that $\mathrm{Pb}$ (II) sorption on different oxides was dominated by different mechanisms. The sorption and complexation of $\mathrm{Eu}(\mathrm{III})$ on alumina as a function of $\mathrm{pH}$, ionic strength and humic acid were investigated by using batch techniques, and the results showed that $\mathrm{Eu}(\mathrm{III})$ sorption was dominated by ion exchange at low $\mathrm{pH}$ and by strong surface complexation at high $\mathrm{pH}$ values [59].

\subsection{Zeolites}

Zeolites are highly porous aluminosilicates with different cavity structures which consist of a three dimensional framework and a negatively charged lattice. The negative charge is balanced by cations which are exchangeable with certain cations in solutions. High ion-exchange capacity and relatively high specific surface areas, and more importantly their relatively low prices, make zeolites attractive adsorb- 
ents in the removal of heavy metal ions [60, 61]. Clino ptilolite is the most abundant and frequently zeolite, which has shown to have high selectivity for certain pollutants [62, 63]. Sharma et al. [64] studied the synthesis and characterization of an analogue of heulandite and its sorption applications for $\mathrm{Th}(\mathrm{IV}), \mathrm{Eu}(\mathrm{III})$, and $\mathrm{Fe}(\mathrm{III})$ recovery from aqueous solutions, and the results indicated that the synthetic analogue of heulandite showed maximum sorption affinity for $\mathrm{Eu}(\mathrm{III})$ and $\mathrm{Fe}(\mathrm{III})$. The sorption of arsenic from aqueous solution on synthetic zeolites H-MFI-24 (H24) and H-MFI-90 (H90) with MFI topology was investigated at room temperature, and the results indicated that $\mathrm{H} 24$ and $\mathrm{H} 90$ zeolites were effective adsorbents for arsenic removal from both high and low initial concentration levels. Both adsorbents reduced arsenic concentration below the WHO s earlier guideline value of $0.05 \mathrm{mg} / \mathrm{L}$ in drinking water [65]. Modified natural mordenite (NM), natural clinoptilolite (NC), HDTMAmodified natural mordenite (SMNM) and HDTMA-modified natural clinoptilolite (SMNC) were proposed for the removal of $\mathrm{As}(\mathrm{V})$ from aqueous solution (HDTMA= hexadecyltrimethylammonium bromide), and showed that surfactantmodified zeolites were effective sorbent for the removal of $\mathrm{As}(\mathrm{V})$ from aqueous solution [66]. The high porous and cavity properties of zeolites make zeolite to have high exchange and complexation ability in the sorption of different heavy metal ions, and the photocatalytic reduction ability of zeolites also make them to reduce the adsorbed high valence metal ions to low valence metal ions, and thereby decreases the mobility and toxicity of metal ions such as $\mathrm{Cr}(\mathrm{VI})$ to $\mathrm{Cr}(\mathrm{III})$ in the natural environment.

\subsection{Other Materials}

There are a lot of other kinds of materials applied for sorption of heavy metal ions from aqueous solutions. Wu et al. [67] studied sorption behavior of some radionuclides on the Chinese weathered coal, and found that the weathered coal is an useful and inexpensive sorbent for the removal of $\mathrm{Am}(\mathrm{III}), \mathrm{Eu}(\mathrm{III})$ and $\mathrm{Cs}(\mathrm{I})$ from aqueous solutions. The mechanism of $\mathrm{Cd}(\mathrm{II})$ sorption by pure calcium carbonate was investigated at laboratory level to examine whether reaction products of phosphate with calcium carbonate serve as a sink for sorption of toxic heavy metal ions like cadmium. It was found that the application of phosphorus on calcareous soils is likely to decrease the retention of $\mathrm{Cd}(\mathrm{II})$ and increase its mobility [68]. Streat et al. [69] used hydrous ferric oxide as adsorbent in wastewater treatment, and found that granular ferric hydroxide can be used for the removal of trace $\mathrm{As}(\mathrm{V})$ from wastewater. Moreover, the release of iron from the adsorbent was found to be negligible under appropriate operating conditions. Removal of dissolved rhenium by sorption onto organic polymers was studied, and the results indicated that a medium with low ionic strength and low concentration of anion competitors retarded the transport of Re and Tc in natural water or soils [70]. Besides the materials mentioned above, there are still many kinds of other sorbents which have high sorption capacity to adsorb heavy metal ions and can be applied to remove different pollutants from aqueous solutions in real work. In future, the materials with high surface area, enough functional groups, high sorption ability, easily separation from aqueous solution, low price, and environmental friendship, may attract more and more interesting in the removal of different heavy metal ions.

\section{KINETICS}

On the purpose of investigating the mechanisms of sorption and its potential rate-controlling steps that include mass transport and chemical reaction process, kinetic models have been exploited to test the experimental data. Sorption kinetics is expressed as the solute rate that controls the residence time of the adsorbate in the solid-solution interface. In practice, kinetic studies were carried out in batch reactions using various initial adsorbate concentrations, sorbent doses, particle sizes, agitation speeds, $\mathrm{pH}$ values and temperatures along with different sorbent and adsorbate types. Then, linear regression was used to determine the best-fitting kinetic rate equation. Generally, sorption of metal ions increased with time until the equilibrium was achieved between the amounts of absorbates adsorbed on the absorbents and the amounts of adsorbates remained in solution. Generally, sorption reactions took place rapidly at initial stages and gradually slowed down in reaching its equilibrium state. The time to reach equilibrium varied with the absorbates, sorbents, initial concentration and the condition of the solution. Many kinetic models were applied to fit the sorption process, which include pseudo-first and pseudo-second-order rate model, Weber and Morris sorption kinetic model, Adam-BohartThomas relation, first-order reversible reaction model, external mass transfer model, first-order equation of Bhattacharya and Venkobachar, Elovich's model and Ritchie's equation [71-74]. The pseudo-first and pseudo-second-order kinetic models are the most well liked models to study the sorption kinetics of sorption and quantify the extent of uptake in sorption kinetics. The $\mathrm{Cu}(\mathrm{II})$ and $\mathrm{Pb}$ (II) sorption by activated carbon from Eucalyptus bark was evaluated, and the kinetics data was appropriately fitted with the pseudo-second-order kinetics model where the sorption rate constant and equilibrium capacities increased with initial heavy metal ion concentration [23]. Sprynskyy et al. [71] concluded that the kinetic sorption process included two main stages: (1) initial rapid sorption (amount of 85-90\%) extended over the first 60 min; and (2) stage of slow approach to equilibrium covering about $8 \mathrm{~h}$. In Azizian's work, [72] the kinetics of sorption were evaluated by pseudo-first-order and pseudo-secondorder models. Although, the pseudo-first-order and pseudosecond-order kinetics models are the simplest models for kinetic modeling of sorption, these models do not fit to experimental data very well and show deviation from linear plots. Sorption behavior of $\mathrm{Ni}(\mathrm{II})$ on nanostructured hydrous titanium oxide was studied [54], and the kinetic data were described by the pseudo-first-order equation well. The kinetic removal of heavy metal ions from water by sorption using surfactant-modified montmorillonite was examined and the pseudo-first-order rate constant was finally evaluated. The plots between dimensionless amount of sorption $\left(\mathrm{Q}_{\mathrm{t}}\right)$ and the approaching equilibrium factor $\left(\mathrm{R}_{\mathrm{w}}\right)$ in pseudosecond-order model were characteristic of sorption processes. According to $\mathrm{R}_{\mathrm{w}}$ values, the characteristic curves were classified into three zones: $1>R_{w}>0.1$ (zone I), $0.1>R_{w}>$ 0.01 (zone II), and $R_{w}<0.01$ (zone III). About $55 \%$ of the published papers surveyed was belonged to zone II [73]. Blanchard et al. [74] reported a similar rate equation for the 
exchange reaction of $\mathrm{NH}_{4}{ }^{+}$ions fixed in zeolite by divalent metal ions in solution. Ho [75] made a review of pseudosecond-order model for sorption systems. Numerous kinetic sorption of metal ions has been studied by the pseudo-firstorder [76-97]. While many works suggested that the pseudosecond-order kinetics model was better to simulate the experimental data. Other kinetic models were not used widely. Baral et al. [97] utilized the Weber and Morris sorption kinetic model to correlate biosorption of $\mathrm{Cr}(\mathrm{VI})$ on treated sawdust, and found that the experimental data were simulated by first-order reversible reaction model very well. It is also interesting to note that many kinetic sorption data can simultaneously simulated by different models well, which does not mean that the experimental data follow different kinetic models. Sometimes, the kinetic models are just an assumption of the sorption process, and do not have any necessary meanings. The frequently used kinetics models are listed in Table $\mathbf{1}$.

Table 1. The Functional Equations of Different Kinetics Models

\begin{tabular}{|l|l|}
\hline Kinetics Model & Functional Form \\
\hline \hline Lagergren model & $\frac{d q}{d t}=k\left(q_{e}-q\right)$ \\
\hline Bhattacharya and Venkobachar model & $\frac{d q}{d t}=k_{1} C-k_{2} C_{s}$ \\
\hline Pseudo-second order model & $\frac{d q}{d t}=k\left(q_{e}-q\right)^{2}$ \\
\hline Elovich model & $\frac{d q}{d t}=\alpha \exp (-\beta q)$ \\
\hline Adam-Bohart-Thomas model & $\frac{d q}{d t}=k_{\text {sorp }} C\left(q_{e}-q\right)-k_{d e s} q$ \\
\hline
\end{tabular}

\section{THERMODYNAMICS}

The thermodynamics of metal ion sorption has been investigated extensively. Generally, there are two common types: endothermal and exothermal sorption processes. If the sorption increases with increasing temperature, it means that the sorption is an endothermal process. Whereas the sorption decreases with increasing temperature, indicates the exothermal sorption process. The thermodynamic parameters such as free energy $\left(\Delta \mathrm{G}^{0}\right)$, enthalpy $\left(\Delta \mathrm{H}^{0}\right)$ and entropy changes $\left(\Delta \mathrm{S}^{0}\right)$ for the sorption of $\mathrm{Cu}$ (II) were computed to predict the nature of sorption process. The removal of $\mathrm{Cu}$ (II) increased with increasing temperature. Negative values of $\Delta \mathrm{G}^{0}$ indicate the feasibility of the process and spontaneous nature of the sorption with a high preference of $\mathrm{Cu}$ (II) for all adsorbents. Positive values of $\Delta \mathrm{H}^{0}$ indicate the endothermic nature of the process, while positive values of $\Delta S^{0}$ reflect the affinity of the adsorbents for $\mathrm{Cu}$ (II) ions and suggest some structural changes in adsorbate and adsorbent [44]. The sorption capacity $\left(\mathrm{Q}_{0}\right)$ increased with the increase in temperature in the case of $\mathrm{Fe}(\mathrm{II})$, thereby indicating the endothermic process in the nature for the $\mathrm{Fe}$ (II)-lignite system. On the other hand, Mn(II) sorption decreased with the increase in temperature, indicating an exothermic process [98]. It was reported that the low enthalpy values reflected the weak dependence of sorption on temperature [99]. In the studies on the capability and behavior of sorption of thallium (III) on nano- $\mathrm{Al}_{2} \mathrm{O}_{3}$, the $\Delta \mathrm{H}^{0}$ and $\Delta \mathrm{G}^{0}$ values of thallium (III) sorption on nano- $\mathrm{Al}_{2} \mathrm{O}_{3}$ showed endothermic sorption process [100]. Yuvaz et al. [101] calculated the $\Delta \mathrm{H}^{0}, \Delta \mathrm{S}^{0}$ and $\Delta \mathrm{G}^{0}$ values of $\mathrm{Cu}(\mathrm{II})$ sorption on Turkish kaolinite to be 39.52 $\mathrm{kJ} \cdot \mathrm{mol}^{-1}, 11.7 \mathrm{~J} \cdot \mathrm{mol}^{-1} \cdot \mathrm{K}^{-1}$ and $4.61 \mathrm{~kJ} \cdot \mathrm{mol}^{-1}$, respectively. Echeverria et al. [102] reported the $\Delta \mathrm{H}^{0}, \Delta \mathrm{S}^{0}$ and $\Delta \mathrm{G}^{0}$ values of $\mathrm{Ni}(\mathrm{II})$ sorption on illite to be $16.8 \mathrm{~kJ} \cdot \mathrm{mol}^{-1}, 58 \mathrm{~J} \cdot \mathrm{mol}^{-1} \cdot \mathrm{K}^{-1}$ and $-1.04 \mathrm{~kJ} \cdot \mathrm{mol}^{-1}$, respectively. Entezari et al. [103] compared the results obtained for the removal of $\mathrm{Cu}(\mathrm{II})$ and $\mathrm{Pb}$ (II) ions from single and binary systems in the presence and absence of ultrasound. The negative values of the standard Gibbs free energy, positive values of the standard enthalpy and positive values of standard entropy changes indicated the spontaneous, endothermic nature of $\mathrm{Cu}^{2+}$ and $\mathrm{Pb}^{2+}$ sorption on the sorbent and the increasing randomness at the solid/liquid interface. The sorption of different heavy metal ions on different sorbents are quite different, and the thermodynamic parameters of metal ion sorption are dominated by the nature of metal ion, nature of sorbents, solution conditions, ionic strength, experimental conditions etc.

\section{SORPTION ISOTHERMS}

Several sorption isotherm models have been applied to describe experimental data of sorption isotherms. The functional forms of the widely used isotherms are listed in Table 2. For the sake of convenience, explicit and simple models are preferred and commonly used; these include several two- and three-parameter isotherm models. The Langmuir and Freundlich models are the most frequently employed models. Freundlich model is an empirical equation and suitable for a highly heterogeneous surface, apart from the ability to represent well in most cases (as shown by high correlation values), a physical meaning of $1 / \mathrm{n}$ was not clear in several studied systems $[79,104,105]$. The Langmuir isotherm based on three assumptions, namely sorption is limited to monolayer coverage, all surface sites are alike and only can accommodate one adsorbed atom and the ability of a molecule to be adsorbed on a given site is independent of its neighboring sites occupancy. Within the Langmuir model, the saturation capacity $\mathrm{q}_{\max }$ is supposed to coincide with saturation of a fixed number of identical surface sites and as such, it should logically be independent of temperature. However, this is opposing the real condition as a small to modest increase [44, 82, 88, 91, 93, 106, 107] and decrease $[94,95,108]$ in $\mathrm{q}_{\max }$ with temperature is generally observed. There are other equations containing two fitting parameters such as Temkin isotherm, Redlich-Paterson isotherm, FloryHuggins and Dubinin-Raduskevich equations, Halsey isotherm, Brunauer-Emmer-Teller (BET) isotherm models. Redlich-Paterson isotherm is the most used three-parameter isotherm model, which is a combination of the Langmuir and Freundlich model. It approaches the Freundlich model at high concentration and is in accord with the low concentration limit of the Langmuir equation. This equation is quite popular for the prediction of heavy metal ion sorption data $[77,94,106,108,109]$. The Toth isotherm model, which is 
similar to the Redlich-Peterson model, combines the characteristics of both the Langmuir and Freundich isotherms. Toth equation posses the correct Henry law type limit besides a parameter to describe the heterogeneities of the system. In addition, Sips isotherm provides a reasonably accurate prediction of heavy metal biosorption experimental results with high value of coefficient correlation $\left(\mathrm{R}^{2}\right)[96,109,110]$. In the sorption of $\mathrm{Cu}(\mathrm{II}), \mathrm{Cd}(\mathrm{II})$ and $\mathrm{Pb}(\mathrm{II})$ on Caulerpa lentillifera, the parameter stays close to unity [96].

Table 2. The Functional Equations of Different Sorption Models

\begin{tabular}{|c|c|}
\hline Isotherm & Functional Form \\
\hline Freundlich & $q_{e}=K_{F} C_{e}^{1 / n}$ \\
\hline Langmuir & $q_{e}=q_{\max } \frac{K_{L} C_{e}}{1+K_{L} C_{e}}$ \\
\hline Temkin & $q_{e}=\frac{R T}{b} \ln \left(a C_{e}\right)$ \\
\hline Dubinin-Radushkevich & $q_{e}=q_{\max } \exp \left(-\left(\frac{R T \ln \left(C_{e} / C_{s}\right)}{\beta E_{0}}\right)^{2}\right)$ \\
\hline Flory-Huggins & $\log \frac{\theta}{C_{0}}=\log K_{F H}+n_{F H} \log (1-\theta)$ \\
\hline Halsey & $q_{e}=\left(\frac{K_{H}}{C_{e}}\right)^{1 / n_{H}}$ \\
\hline $\begin{array}{c}\text { Brunauer, Emmett and } \\
\text { Teller(BET) }\end{array}$ & $q_{e}=q_{\max } \frac{B C_{e}}{q_{\max }\left(C_{e}-C_{s}\right)\left[1+(B-1)\left(C_{e} / C_{s}\right)\right]}$ \\
\hline Sips & $q_{e}=q_{\max } \frac{\left(K_{S} C_{e}\right)^{\gamma}}{\left(1+\left(K_{S} C_{e}\right)^{\gamma}\right)}$ \\
\hline Toth & $q_{e}=q_{\max } \frac{b_{T} C_{e}}{\left(1+\left(b_{T} C_{e}\right)^{n_{T}}\right)^{1 / n_{T}}}$ \\
\hline Redlich-Paterson & $q_{e}=\frac{K_{R P} C_{e}}{1+a_{R P} C_{e}^{\beta}}$ \\
\hline
\end{tabular}

Nomenclature

$\mathrm{C}_{\mathrm{e}}$ equilibrium concentration

$\mathrm{C}_{\mathrm{s}}$ adsorbate solubility at a given temperature

$\mathrm{E}_{0}$ solid characteristic energy towards a reference compound

$\mathrm{q}_{\mathrm{e}}$ amount adsorbed

$\mathrm{q}_{\max }$ saturated monolayer sorption capacity

In the kinetics equations

$\mathrm{q}_{\mathrm{e}}$ the amount of solute adsorbed at equilibrium

$\mathrm{q}$ the amount of solute adsorbed at any given time ' $\mathrm{t}$ '

$\mathrm{C}$ the concentrations of sorbate in solution at any given time ' $\mathrm{t}$ '

$\mathrm{C}_{\mathrm{s}}$ the concentrations of sorbate in sorbent at any time ' $\mathrm{t}$ '

others parameters or constants.

\section{SORPTION MECHANISM}

In order to understand the mechanism of the sorption, large quantities of work have been done to investigate the influence of the sorption process using different kinds of technologies such as Fourier Transform Infrared (FTIR) spectroscopy, [11] Attenuated Total Reflection Infrared (ATR-IR) spectroscopy, [56] X-ray diffraction (XRD), [111] electrophoretic mobility (EM), [112] extend X-ray absorption fine structure (EXAFS) spectroscopy [14, 24, 113, 114] etc. The main mechanisms include hydrogen-bonding physisorption, chemisorption, ion exchange and precipitation. Usually, in the batch experiments, different $\mathrm{pH}[21,44,55$, 115-119] and different ionic strengths [31, 120] were carried out to check their effect on the sorption of metal ions. For most cases, chemisorption is the main mechanism of metal ions at high $\mathrm{pH}$ values $[11,14,18,31,56,69,112,118,120$ 122]. Surface complexation model is usually applied to simulate the sorption data of metal ions on different solid particles [43, 55, 123]. In many other cases, surface complexation and ionic exchange were considered as the main mechanisms at different experimental conditions [124-128]. Thakur et al. [68] reported that the Cd(II) was effectively retained on $\mathrm{CaCO}_{3}$ by the mechanism of chemisorption at low $\mathrm{Cd}(\mathrm{II})$ concentrations as the $\mathrm{pH}$ of the equilibrium system remained constant (8.6). At high concentrations, precipitation of $\mathrm{CdCO}_{3}$ on $\mathrm{CaCO}_{3}$ surface or as a separate phase predominated $\mathrm{Cd}(\mathrm{II})$ sorption. Debnath et al. [54] studied $\mathrm{Ni}$ (II) sorption on nanostructured hydrous titanium oxides, and found that the mean energy of sorption $\left(\mathrm{E}_{\mathrm{DR}}=13.25\right.$ $16.35 \mathrm{~kJ} \cdot \mathrm{mol}^{-1}$ at $\mathrm{T}=288-328 \mathrm{~K}$ ) suggested the physisorption mechanism of $\mathrm{Ni}(\mathrm{II})$ on NHTO. Partey et al. [112] investigated arsenic sorption mechanisms onto laterite iron concretions (LIC) using electrophoretic mobility (EM) measurements and attenuated total reflectance-Fourier transform infrared spectroscopy (ATR-FTIR), and they found that the results of electrophoretic mobility implied both As(III) and $\mathrm{As}(\mathrm{V})$ formed inner-sphere complexes on the LIC. The FTIR studies suggested that both $\mathrm{As}(\mathrm{III})$ and $\mathrm{As}(\mathrm{V})$ also formed inner-sphere complexes with LIC. The surface complexation model assumed that all mineral phases contributing to sorption are represented by one type of surface group. Tan et al. [129] used XPS and EXAFS to study Eu(III) sorption onto $\mathrm{TiO}_{2}$. The XPS analysis showed that Eu(III) was chemically present within the near-surface of $\mathrm{TiO}_{2}$ due to the formation of -SOEu and -SOHAEu complexes in the presence of humic acid. EXAFS technique was applied to characterize the local atomic structural environment of the adsorbed Eu(III), and the results indicated that $\mathrm{Eu}(\mathrm{III})$ was bound to about seven or eight $\mathrm{O}$ atoms at an interatomic distance of about

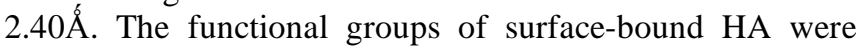
expected to be involved in the sorption process. The measured $\mathrm{Eu}-\mathrm{Ti}$ interatomic distance confirmed the formation of inner-sphere sorption complexes on $\mathrm{TiO}_{2}$ surfaces. Fig. (1) shows the XPS spectra of Eu(III) adsorbed on bare and HArutile hybrids at $\mathrm{pH}$ 4.0. The adsorbed Eu (III) can be readily identified by Eu $3 \mathrm{~d}$ XPS lines. The $\mathrm{k}^{2}$-weighted fluorescence Eu $\mathrm{L}_{\mathrm{III}}$-edge EXAFS spectra and the corresponding Fourier transforms for the samples are shown in Fig. (2). Fig. (3) and Fig. (4) also show the deduced results in the analysis of EXAFS spectra in some sorption systems [14, 116]. To better understand the sorption mechanism, much endeavor has been done on the modifying of adsorbents. For example, two of the common techniques in modifying clay are intercalation and pillaring, and acid activation. XRD measurements show that intercalation increases the spacing between adjacent layers. In clays pillared by various inorganic or organic compounds, the two-dimensional silicate layers with thickness of about $1 \mathrm{~nm}$ are kept apart by ceramic oxides with a dimension of nano- to subnano-metre sizes. The pillaring 


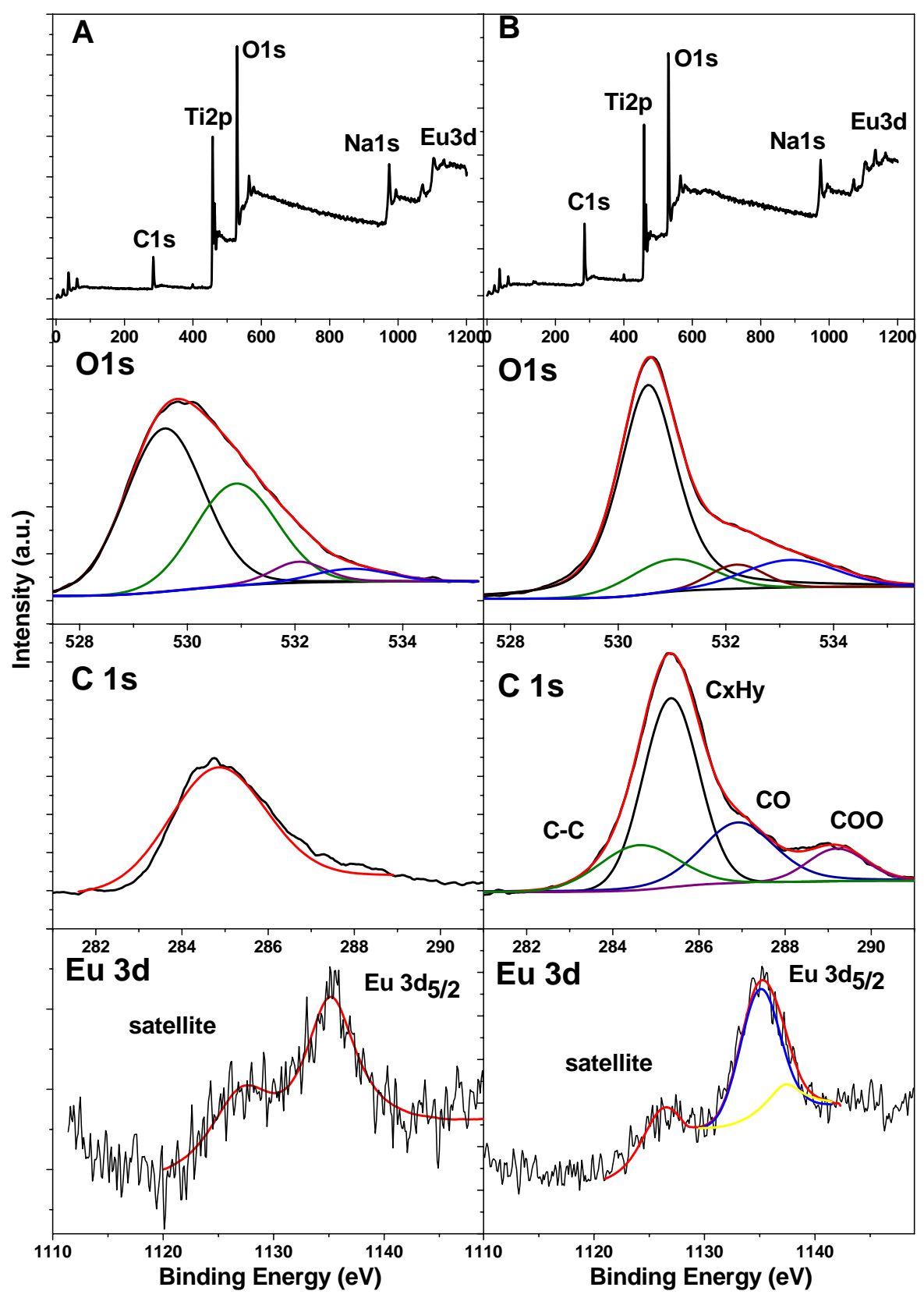

Fig. (1). XPS spectra of the survey, O 1s, C 1s, and Eu 3d; (A) rutile/Eu(III) hybrids and (B) rutile/HA/Eu(III) hybrids. C1s and O1s spectrum of the rutile/HA/Eu(III) system is the result of a fit curve. $\mathrm{C}\left(\mathrm{TiO}_{2}\right)=0.3 \mathrm{~g} / \mathrm{L}, \mathrm{C}[\mathrm{Eu}(\mathrm{III})]_{\text {initial }}=3.0 \times 10^{-5} \mathrm{~mol} / \mathrm{L}, \mathrm{C}(\mathrm{NaClO})_{4}=0.01 \mathrm{~mol} / \mathrm{L}$, $\mathrm{C}(\mathrm{HA})_{\text {initial }}=7.5 \mathrm{mg} / \mathrm{L}, \mathrm{pH} 4.0, \mathrm{~T}=25^{\circ} \mathrm{C}$. [129].

process is generally presented as a way of increasing the accessibility of the clay layers, but an alternative viewpoint is that it stabilizes 'oxide' particles of nanometer dimension that prevent aggregation by interaction with the layers. The surface groups exposed by these ultradispersed 'oxides' probably play a key role in determining the promising adsorptive and catalytic properties of pillared clays. Acid treatments of clay minerals with inorganic acid of rather high concentration and usually at high temperature are an important control over mineral weathering and genesis. Such treatments can often replace exchangeable cations with $\mathrm{H}^{+}$ and $\mathrm{Al}^{3+}$ ions and other cations escape out of both tetrahedral and octahedral sites, leaving $\mathrm{SiO}_{4}$ groups largely intact, which generally increases the surface area and acidity of the clay minerals, along with the elimination of several mineral impurities and partial dissolution of the external layers. The modified materials showed higher sorption capacity in the removal of heavy metal ions than the untreated materials [16, $29,36,45,130-135]$. Other methods such as treatment with surfactants, [66, 136-138] modified by the sorption of fulvic acid [139, 140] or in the condition of ultrasonic [141, 142] also improved the sorption capacity, which is attributed to the increasing functional groups on the surfaces. Tan et al. [143] studied the effect of humic acid (HA) and fulvic acid (FA) on the sorption and species of Eu (III) on alumina by using time resolved laser fluorescence spectroscopy, and found that the presence of HA and FA affected the sorption of Eu (III) obviously (Fig. 5). Fan et al. [144] studied the effect 

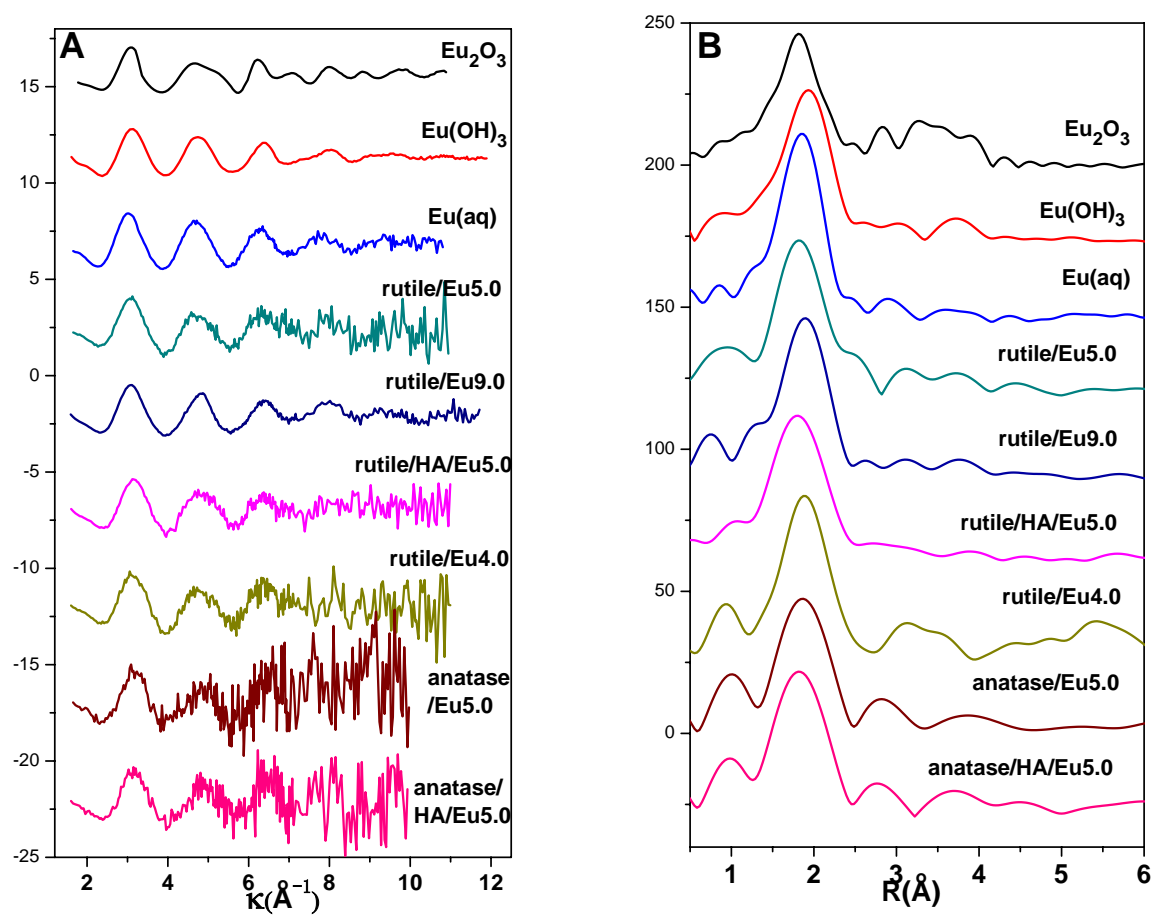

Fig. (2). $\mathrm{k}^{2}$-weighted EXAFS spectra (A) and the corresponding Fourier transforms (B) of the following reference and sorption samples: $\mathrm{Eu}(\mathrm{III})$ adsorbed onto rutile at $\mathrm{pH} 5.0$ (rutile/Eu5.0), at $\mathrm{pH} 4.0$ (rutile/Eu4.0), and at pH 9.0 (rutile/Eu9.0); the presence of HA at pH 5.0 (rutile/HA/Eu5.0 and anatase/HA/Eu5.0); and $\mathrm{Eu}(\mathrm{III})$ adsorbed onto anatase at pH 5.0 (anatase/Eu5.0). C(TiO 2$)=0.3 \mathrm{~g} / \mathrm{L}, \mathrm{C}[\mathrm{Eu}(\mathrm{III})]_{\text {initial }}$ $=3.0 \times 10^{-5} \mathrm{~mol} / \mathrm{L}, \mathrm{C}\left(\mathrm{NaClO}_{4}\right)=0.01 \mathrm{~mol} / \mathrm{L}, \mathrm{C}(\mathrm{HA})_{\text {initial }}=7.5 \mathrm{mg} / \mathrm{L}, \mathrm{pH} 4.0$ or 5.0 or $9.0, \mathrm{~T}=25{ }^{\circ} \mathrm{C}[129]$.

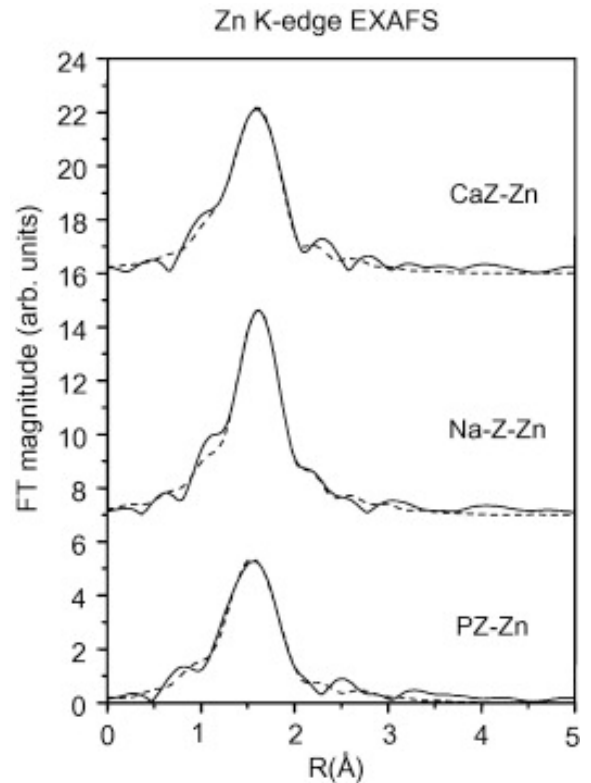

Fig. (3). Fourier transform magnitudes of the $\mathrm{k}^{3}$-weighted $\mathrm{Zn}$ EXAFS spectra of the PZ-Zn, NaZ-Zn and CaZ-Zn samples calculated in the $\mathrm{k}$ range of $3-11 \AA^{-1}$, $\mathrm{k}$ range of $2.7-11 \AA^{-1}$ and $\mathrm{k}$ range of 3-11 $\AA^{-1}$ respectively (solid line - experiment, dashed line EXAFS model) [116].

of HA and FA on the sorption of Eu (III) on attapulgite by batch and EXAFS techaniques, and found that the effect of $\mathrm{HA}$ and FA on the sorption and microstructures of Eu (III) on attapulgite at different $\mathrm{pH}$ values are quite different, and the coordination numbers of $\mathrm{O}$ atoms in the first shell of $\mathrm{Eu}$ (III) and the bond distances of $\mathrm{Eu}$ and $\mathrm{O}$ are different at

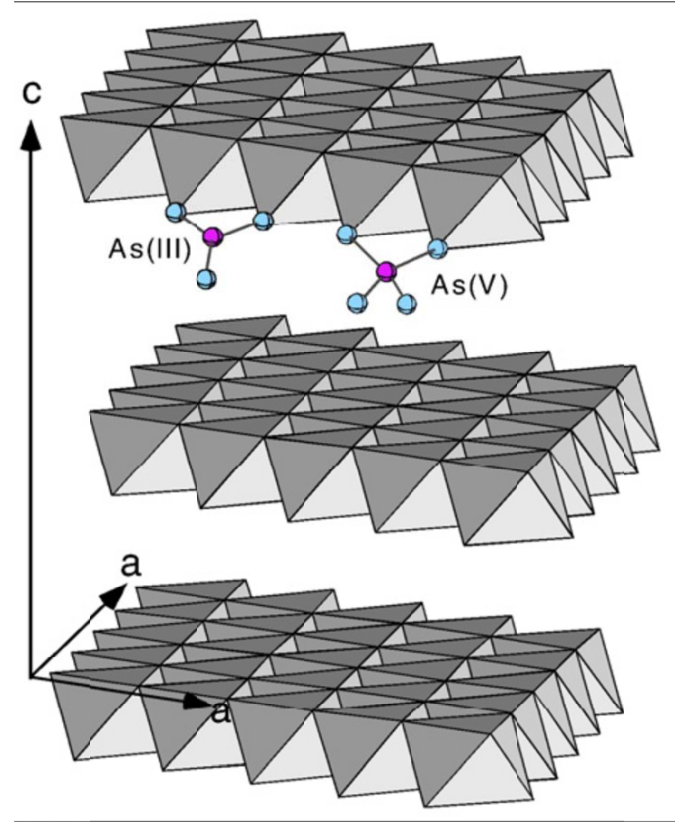

Fig. (4). Proposed surface complexation of As(III) and As(V) on green rust [14].

different $\mathrm{pH}$ values. Fig. (6). All these results indicate that the presence of HA or FA not only affects the sorption properties of heavy metal ion on solid particles, but also affects the microstructures and species of heavy metal ions at different experimental conditions. 


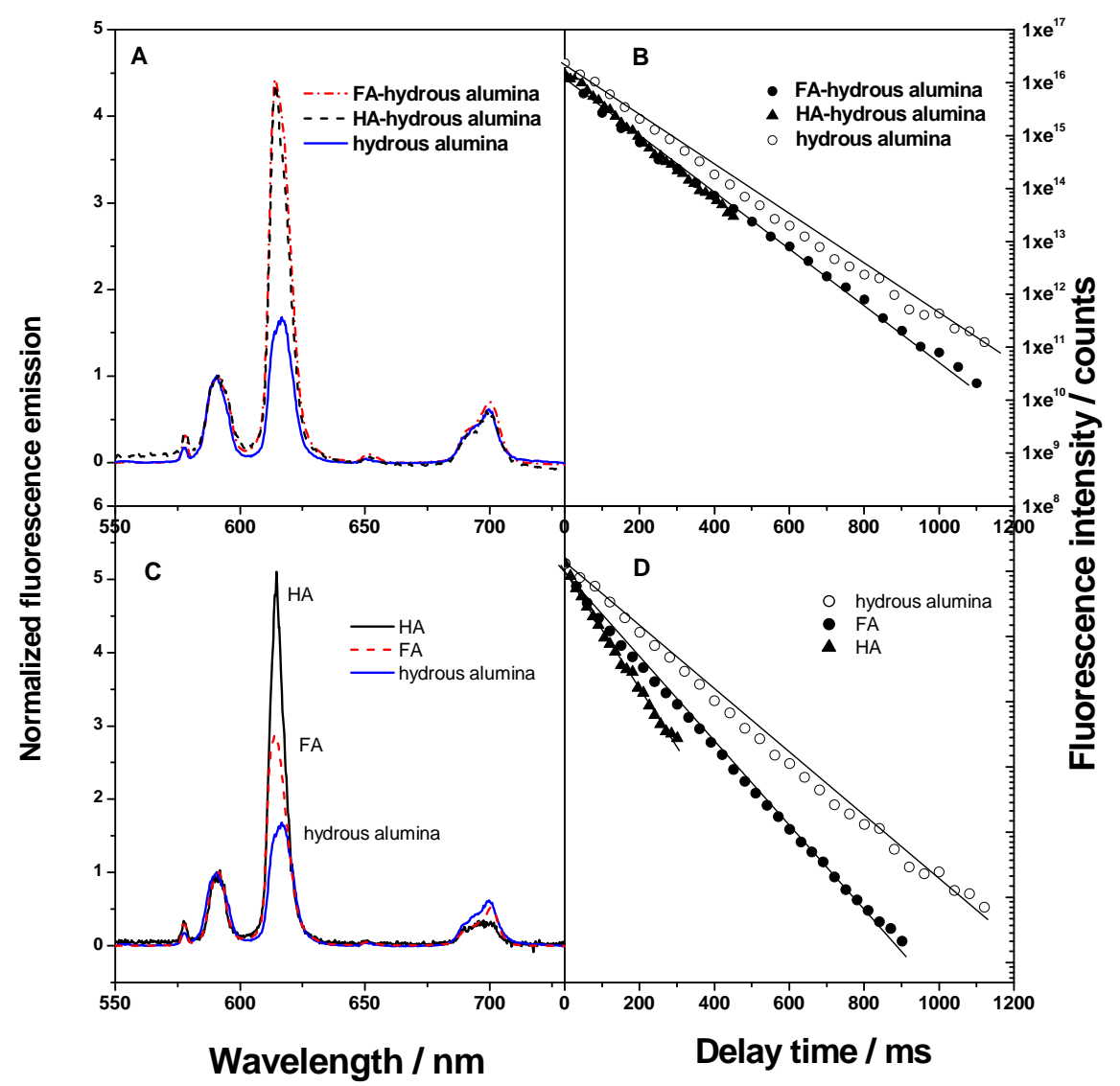

Fig. (5). TRLFS results for Eu(III) bound to HA, FA, hydrous alumina, HA-hydrous alumina and FA-hydrous alumina hybrids. C(hydrous alumina $)=4.4 \mathrm{~g} / \mathrm{L}, \mathrm{C}(\mathrm{Eu}(\mathrm{III}))_{(\text {initial })}=4.3 \times 10^{-5} \mathrm{~mol} / \mathrm{L}, \mathrm{C}(\mathrm{FA} / \mathrm{HA})_{\text {(initial) }}=10 \mathrm{mg} / \mathrm{L}, \mathrm{C}\left(\mathrm{KNO}_{3}\right)=0.1 \mathrm{~mol} / \mathrm{L}, \mathrm{pH}=6.3 \pm 0.1, \mathrm{~T}=20 \pm 1^{\circ} \mathrm{C}[143]$.
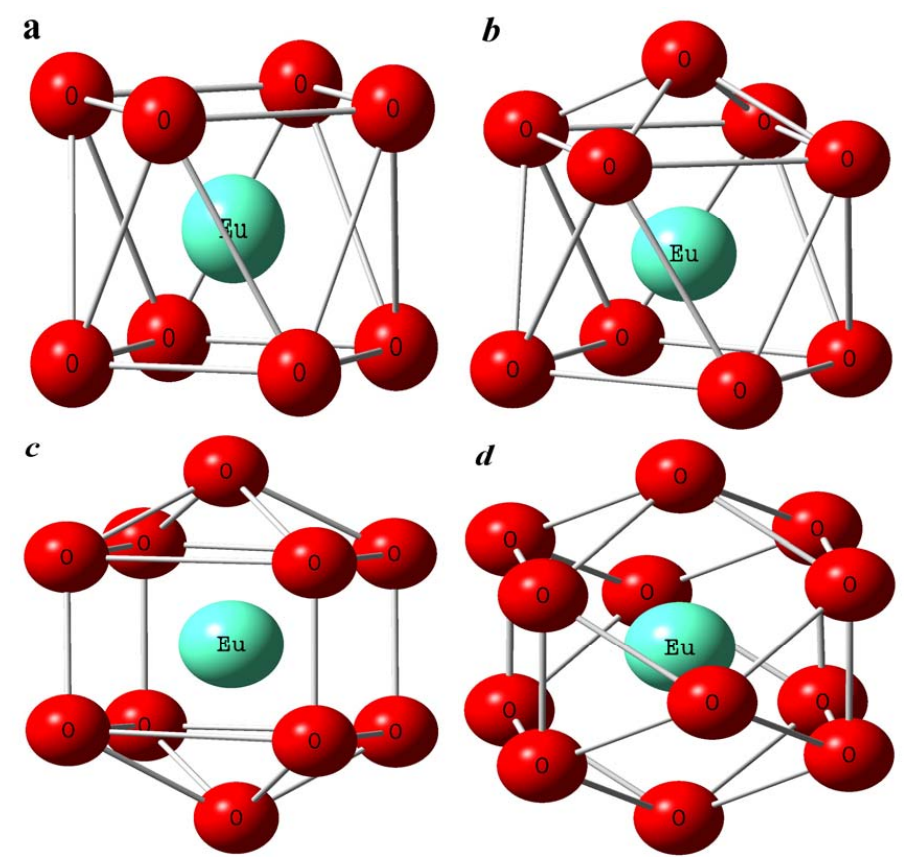

Fig. (6). The different imaginary Eu (III) structures according to EXAFS results of the first order coordination shells. (a): dodecahedron; (b): mono-crown anti-tetragonal-prism; (c): bi-crown-dodecahedron; (d): icosahedron [144].

\section{CONCLUSION AND FUTURE WORK}

Different types of adsorbents including natural materials and some artificial materials like clay minerals, biosorbents, carbon-materials, metal oxides are summarized. The kinetics, thermodynamics, sorption mechanisms of metal ions on different adsorbents at different experimental conditions are discussed and compared. According to the studies, there ex- 
ists some relationship between sorption properties and the structure of the adsorbate or the surface properties and groups of the adsorbent, besides the surface area/porosity effect. Although much research has been done on the sorption process, there are still many amphibolous matters for further research, such as the quantificational relationship between the pore size distribution of adsorbent, size of adsorbate molecules, functional groups present on the surface of adsorbent, batch or column conditions, particle size of adsorbent and the sorption capacity, which will help in predicting and selecting adsorbents in the application of real work. As for the study in the sorption mechanism, more proof is needed in order to get the confessed modality of heavy metal ions on the different adsorbents, which requires new analytical methods for test. Some researchers confirmed that the batch technique contains various sources of uncertainty and brings relevant uncertainty to determine sorption parameters. It has been shown that experimental procedure represents important source of uncertainties and a great part of final distribution coefficient uncertainty comes from this source. For performance assessment studies in the future, understanding the variation in distribution coefficient uncertainty sources is important to weigh the influence of experimental setup on final sorption data.

Besides the studies of single-component sorption of heavy metal ions, multi-component sorption should be focused in future. In the wastewater treatment, the interaction among the different metal ions in solution will play an important role in the sorption efficiency of different metal ions. Considering the economy of adsorbents, it is necessary to synthesize low-cost, effective and recyclable adsorbents for its extensive application in our daily life. The adsorbents with high sorption capacity, easy separation from aqueous solution, low cost and recycling use are promising materials in future. The high selectivity for the interested metal ion is most important for the materials in the removal of special interested metal ions from large volumes of aqueous solutions.

\section{ACKNOWLEDGEMENT}

Financial support from National Natural Science Foundation of China (20907055; 20971126; 21071147; 21077107), 973 projects from Ministry of Science and Technology of China (2007CB936602; 2011CB933700) and Anhui Province Technology Fund for Outstanding Youths (10040606Y34) are acknowledged.

\section{REFERENCES}

[1] Anderson, C.; Bard, A.J. An Improved Photocatalyst of $\mathrm{TiO}_{2} /$ $\mathrm{SiO}_{2}$ Prepared by a Sol-Gel Synthesis. J. Phys. Chem., 1995, 99, 9882-9885.

[2] Takeda, N.; Ohtani, M.; Torimoto, T.; Kuwabata, S.; Yoneyama, H. Evaluation of Diffusibility of Adsorbed Propionaldehyde on Titanium Dioxide-Loaded Adsorbent Photocatalyst Films from Its Photodecomposition Rate. J. Phys. Chem. B, 1997, 101, 2644-2649.

[3] Bhattacharyya, A.; Kawi, S.; Ray, M.B. Photocatalytic degradation of orange II by $\mathrm{TiO}_{2}$ catalysts supported on adsorbents. Catal. Today., 2004, 98, 431-439.

[4] Machado, L.C.R.; Torchia, C.B.; Lago, R.M. Floating photocatalysts based on $\mathrm{TiO}_{2}$ supported on high surface area exfoliated vermiculite for water decontamination. Catal. Commun., 2006, 7, 538-541.

[5] Qu, J. Research progress of novel adsorption processes in water purification: A review. J. Environ. Sci., 2008, 20, 1-13.
[6] Anyanwu, E.E. Review of solid adsorption solar refrigeration II: An overview of the principles and theory. Energy Convers. Manage., 2004, 45, 1279-1295.

[7] Yu, X.; Zhu, L.; Guo, B.; He, S. Adsorption of mercury on laterite from Guizhou Province, China. J. Environ. Sci., 2008, 20, 13281334.

[8] Bergaoui, L.; Lambert, J.F.; Prost, R. Cesium adsorption on soil clay: macroscopic and pectroscopic measurements. Appl. Clay. Sci., 2005, 29, 23-29.

[9] Giannakopoulou, F.; Haidouti, C.; Chronopoulou, A.; Gasparatos, D. Sorption behavior of cesium on various soils under different $\mathrm{pH}$ levels. J. Hazard. Mat., 2007, 149, 553-556.

[10] Li, D.; Huang, S.; Wang, W.; Peng, A. Study on the kinetics of cerium(III) adsorption-desorption on different soils of China. Chemosphere., 2001, 44 ,663-669.

[11] Abollino, O.; Aceto, M.; Malandrino, M.; Sarzanini, C.; Mentasti, E. Adsorption of heavy metals on Na-montmorillonite. Effect of pH and organic substances. Water. Res., 2003, 37, 1619-1627.

[12] Badillo-Almaraz, V.E.; Ly, J. Calcium sorption on hydroxyapatite in aqueous solutions: reversible and nonreversible components. $J$. Colloid. Interf. Sci., 2003, 258, 27-32.

[13] Al-Degs, Y.S.; El-Barghouthi, M.I.; Issa, A.A.; Khraisheh, M.A.; Walker, G.M. Sorption of $\mathrm{Zn}$ (II), $\mathrm{Pb}$ (II), and $\mathrm{Co}$ (II) using natural sorbents: Equilibrium and kinetic studies. Water. Res., 2006, 40, 2645-2658.

[14] Jönsson, J.; Sherman, D.M. Sorption of $\mathrm{As}(\mathrm{III})$ and $\mathrm{As}(\mathrm{V})$ to siderite, green rust (fougerite) and magnetite: Implications for arsenic release in anoxic groundwaters. Chem. Geol., 2008, 255, 173-181.

[15] Dixit, S.; Hering, J.G. Sorption of Fe(II) and As(III) on goethite in single- and dual-sorbate systems. Chem. Geol., 2006, 228, 6-15.

[16] Unuabonah, E.I.; Adebowale, K.O.; Olu-Owolabi, B.I.; Yang, L.Z.; Kong, L.X. Adsorption of $\mathrm{Pb}$ (II) and $\mathrm{Cd}$ (II) from aqueous solutions onto sodium tetraborate-modified Kaolinite clay: Equilibrium and thermodynamic studies. Hydrometallurgy, 2008, 93, 1-9.

[17] Burch R.; Warburton CI. Zr-Containing pillared interlayer clays: I. Preparation and structural characterisation. J. Catal., 1986, 97, 503510.

[18] Wu, P.; Wu, W.; Li, S.; Removal of $\mathrm{Cd}^{2+}$ from aqueous solution by adsorption using Fe-montmorillonite. J. Hazard. Matter, 2009, 169, 824-830.

[19] Christidis, G.E.; Scott, P.W.; Dunham, A.C. Acid activation and bleaching capacity of bentonites from the islands of Milos and Chios, Aegean, Greece. Appl. Clay. Sci., 1997, 12, 329-347.

[20] Di Natale, F.; Erto, A.; Lancia, A.; Musmarra, D. Experimental and modelling analysis of $\mathrm{As}(\mathrm{V})$ ions adsorption on granular activated carbon. Water. Res., 2008, 42, 2007-2016.

[21] Selvi, K.; Pattabhi, S.; Kadirvelu, K. Removal of $\mathrm{Cr}(\mathrm{VI})$ from aqueous solution by adsorption onto activated carbon. Bioresource. Technol., 2001, 80, 87-89.

[22] Graydon, J.W.; Zhang, X.; Kirk, D.W.; Jia, C.Q. Sorption and stability of mercury on activated carbon for emission control. $J$. Hazard. Matter, 2009, 168, 978-982.

[23] Patnukao, P.; Kongsuwan, A.; Pavasant, P. Batch studies of adsorption of copper and lead on activated carbon from Eucalyptus camaldulensis Dehn. bark. J. Environ. Sci., 2008, 20, 1028-1034.

[24] Ewecharoen, A.; Thiravetyan, P.; Wendel, E.; Bertagnolli, H. Nickel adsorption by sodium polyacrylate-grafted activated carbon. J. Hazard. Matter., 2009, 171, 335-339.

[25] Li, Y.H.; Wang, S.; Wei, J.; Zhang, X.; Xu, C.; Luan, Z.; Wu, D.; Wei, B. Lead adsorption on carbon nanotubes. Chem. Phys. Lett., 2002, 357, 263-266.

[26] Li, Y.H.; Wang, S.; Luan, Z.; Ding, J.; Xu, C.; Wu, D. Adsorption of cadmium(II) from aqueous solution by surface oxidized carbon nanotubes. Carbon., 2003, 41, 1057-1062.

[27] Di, Z.C.; Ding, J.; Peng, X.J.; Li, H.Y.; Luan, K.Z.; Liang, J. Chromium adsorption by aligned carbon nanotubes supported ceria nanoparticles. Chemosphere., 2006, 62, 861-865.

[28] Li, Y.H.; Ding, J.; Luan, Z.; Di, J.; Zhu, Y.; Xu, C.; Wu, D.; Wei, B. Competitive adsorption of $\mathrm{Pb}^{2+}, \mathrm{Cu}^{2+}$ and $\mathrm{Cd}^{2+}$ ions from aqueous solutions by multiwalled carbon nanotubes. Carbon., 2003, 41, 2787-2792.

[29] Gao, Z.; Bandosz, T.J.; Zhao, Z.; Han, M.; Qiu, J. Investigation of factors affecting adsorption of transition metals on oxidized carbon nanotubes. J. Hazard. Matter., 2009, 167, 357-365. 
[30] Wang, X.; Chen, C.; Hu, W. Sorption of ${ }^{243} \mathrm{Am}$ (III) to Multiwall Carbon Nanotubes. Environ. Sci. Technol. 2005, 39(8), 2856-2860.

[31] Xu, D.; Tan, X.; Chen, C.; Wang, X. Removal of Pb(II) from aqueous solution by oxidized multiwalled carbon nanotubes. $J$. Hazard. Matter., 2008, 154, 407-416.

[32] Chen, C.; Wang, X. Adsorption of Ni(II) from Aqueous Solution Using Oxidized Multiwall Carbon Nanotubes. Ind. Eng. Chem. Res., 2006, 45, 9144-9149.

[33] Chen, C.; Li, X.; Zhao, D.; Tan, X.; Wang, X. Adsorption kinetic, thermodynamic and desorption studies of Th(IV) on oxidized multi-wall carbon nanotubes. Colloid. Surf. A: Physicochem. Eng. Aspects., 2007, 302, 449-454.

[34] Tan, X.; Xu, D.; Chen, C.; Wang, X.; Hu, W. Adsorption and kinetic desorption study of ${ }^{152+154} \mathrm{Eu}(\mathrm{III})$ on multiwall carbon nanotubes from aqueous solution by using chelating resin and XPS methods. Radiochim. Acta., 2008, 96, 23-29.

[35] Chen, C.; Hu, J.; Xu, D. Surface complexation modeling of $\mathrm{Sr}$ (II) and $\mathrm{Eu}(\mathrm{III})$ adsorption onto oxidized multiwall carbon nanotubes. J. Colloid. Interface Sci., 2008, 323, 33-41.

[36] Rao, G.P.; Lu, C.; Su, F. Sorption of divalent metal ions from aqueous solution by carbon nanotubes: A review. Sep. Purif. Technol., 2007, 58, 224-231.

[37] Volesky, B.; Holan, Z.R. Biosorption of heavy metals. Biotechnol. Progress., 1995, 11, 235-250.

[38] Lee, H.S.; Volesky, B. Interaction of light metals and protons with seaweed biosorbent. Water. Res., 1997, 31, 3082-3088.

[39] Kratochvil, D.; Pimentel, P.; Volesky, B. Removal of Trivalent and Hexavalent Chromium by Seaweed Biosorbent. Environ. Sci. Technol., 1998, 32, 2693-2698.

[40] Pagnanelli, F.; Mainelli, S.; Vegli, F.; Toro, L. Heavy metal removal by olive pomace: biosorbent characterisation and equilibrium modelling. Chem. Eng. Sci., 2003, 58, 4709-4717.

[41] Shin, E.W.; Rowell, R.M. Cadmium ion sorption onto lignocellulosic biosorbent modified by sulfonation: the origin of sorption capacity improvement. Chemosphere., 2005, 60, 10541061.

[42] Park, D.; Yun, Y.S.; Jo, J.H.; Park, J.M. Biosorption process for treatment of electroplating wastewater containing $\operatorname{cr}(\mathrm{vi})$ : laboratory-scale feasibility test. Ind. Eng. Chem. Res., 2006, 45, 5059-5065.

[43] Guo, X.; Zhang, S.; Shan, X.Q. Adsorption of metal ions on lignin. J. Hazard. Matter., 2008, 151, 134-142.

[44] AydIn, H.; Bulut, Y.; Yerlikaya, Ç. Removal of copper (II) from aqueous solution by adsorption onto low-cost adsorbents. $J$. Environ. Manage, 2008, 87, 37-45.

[45] Kumar, U.; Bandyopadhyay, M. Sorption of cadmium from aqueous solution using pretreated rice husk. Bioresource. Technol., 2006, 97, 104-109.

[46] Conrad, K.; Bruun.; Hansen, H,C. Sorption of zinc and lead on coir. Bioresource. Technol., 2007, 98, 89-97.

[47] Wan Ngah, W.S.; Hanafiah, M.A.K.M. Removal of heavy metal ions from wastewater by chemically modified plant wastes as adsorbents: A review. Bioresource. Technol., 2008, 99, 3935-3948.

[48] Guibal, E. Interactions of metal ions with chitosan-based sorbents: a review. Sep. Purif. Technol., 2004, 38, 43-74.

[49] Miretzky, P.; Cirelli, A.F. Hg(II) removal from water by chitosan and chitosan derivatives: A review. J. Hazard. Matter., 2009, 167, 10-23.

[50] Hagfeldt, A.; Graetzel, M. Light-induced redox reactions in nanocrystalline systems. Chem. Rev., 1995, 95, 49-68.

[51] Zhang, L.; Kanki, T.; Sano, N.; Toyoda, A. Development of $\mathrm{TiO}_{2}$ photocatalyst reaction for water purification. Sep. Purif. Technol., 2003, 31, 105-110.

[52] Mohammadi, M.R.; Fray, D.J.; Cordero-Cabrera, M.C. Sensor performance of nanostructured $\mathrm{TiO}_{2}$ thin films derived from particulate sol-gel route and polymeric fugitive agents. Sensor. Actuat. B: Chem., 2007, 124, 74-83.

[53] Moser, J.E.; Bonnôte, P.; Grätzel M. Molecular photovoltaics. Coordin. Chem. Rev., 1998, 171, 245-250.

[54] Debnath, S.; Ghosh, U.C. Nanostructured hydrous titanium(IV) oxide: Synthesis, characterization and $\mathrm{Ni}(\mathrm{II})$ adsorption behavior. Chem. Eng. J., 2009, 152, 480-491.

[55] Shi, K.; Wang, X.; Guo, Z.; Wang, S.; Wu, W. Se(IV) sorption on $\mathrm{TiO}_{2}$ : Sorption kinetics and surface complexation modeling. Colloid. Surf. A: Physicochem. Eng. Aspects., 2009, 349, 90-95.
[56] Lefèvre, G.; Kneppers, J.F.; Fédoroff, M. Sorption of uranyl ions on titanium oxide studied by ATR-IR spectroscopy. J. Colloid. Interface Sci., 2008, 327, 15-20.

[57] Nano, G.V.; Strathmann, T.J. Ferrous iron sorption by hydrous metal oxides. J. Colloid. Interf. Sci., 2006, 297, 443-454.

[58] O'Reilly, S.E.; Hochella, M.F. Lead sorption efficiencies of natural and synthetic $\mathrm{Mn}$ and Fe-oxides. Geochim. Cosmochim. Acta., 2003, 67, 4471-4487.

[59] Wang, X.; Xu, D.; Chen, L. Sorption and complexation of Eu(III) on alumina: Effects of $\mathrm{pH}$, ionic strength, humic acid and chelating resin on kinetic dissociation study. Appl. Radiat. Isot., 2006, 64, 414-421.

[60] Armagan, B.; Turan Melik, M.S. Equilibrium studies on the adsorption of reactive azo dyes into zeolite. Desalination., 2004, 170, 33-39.

[61] Benkli, Y.E.; Can, M.F.; Turan, M.; Çelik, M.S. Modification of organo-zeolite surface for the removal of reactive azo dyes in fixed-bed reactors. Water. Res., 2005, 39, 487-493.

[62] Wang, Y.F.; Lin, F.; Pang, W.Q. Ammonium exchange in aqueous solution using Chinese natural clinoptilolite and modified zeolite. $J$. Hazard. Matter., 2007, 142, 160-164.

[63] Kowalczyk, P.; Sprynskyy, M.; Terzyk, A.P. Porous structure of natural and modified clinoptilolites. J. Colloid. Interface Sci., 2006, 297, 77-85.

[64] Sharma, P.; Singh, G.; Tomar, R. Synthesis and characterization of an analogue of heulandite: Sorption applications for thorium(IV), europium(III), samarium(II) and iron(III) recovery from aqueous waste. J. Colloid. Interf. Sci., 2009, 332, 298-308.

[65] Chutia, P.; Kato, S.; Kojima, T.; Satokawa, S. Arsenic adsorption from aqueous solution on synthetic zeolites. J. Hazard. Matter., 2009, 162, 440-447.

[66] Chutia, P.; Kato, S.; Kojima, T.; Satokawa, S. Adsorption of As(V) on surfactant-modified natural zeolites. J. Hazard. Matter., 2009, 162, 204-211.

[67] Wu, J.; Xu, Q.; Bai, T. Adsorption behavior of some radionuclides on the Chinese weathered coal. Appl. Radiat. Isot., 2007, 65, 901909.

[68] Thakur, S.K.; Tomar, N.K.; Pandeya, S.B. Influence of phosphate on cadmium sorption by calcium carbonate. Geoderma., 2006, 130, 240-249.

[69] Streat, M.; Hellgardt, K.; Newton, N.L.R. Hydrous ferric oxide as an adsorbent in water treatment: Part 2. Adsorption studies. Process. Saf. Environ. Protect., 2008, 86, 11-20.

[70] Kim, E.; Benedetti, M.F.; Boulègue, J. Removal of dissolved rhenium by sorption onto organic polymers: study of rhenium as an analogue of radioactive technetium. Water. Res., 2004, 38, 448-454.

[71] Sprynskyy, M.; Ligor, T.; Lebedynets, M.; Buszewski, B. Kinetic and equilibrium studies of phenol adsorption by natural and modified forms of the clinoptilolite. J. Hazard. Matter, 2009, 169, 847-854.

[72] Azizian, S.; Haerifar, M.; Bashiri, H. Adsorption of methyl violet onto granular activated carbon: Equilibrium, kinetics and modeling. Chem. Eng. J., 2009, 146, 36-41.

[73] Wu, F.C.; Tseng, R.L.; Huang, S.C.; Juang, R.S. Characteristics of pseudo-second-order kinetic model for liquid-phase adsorption: A mini-review. Chem. Eng. J., 2009, 151, 1-9.

[74] Blanchard, G.; Maunaye, M.; Martin, G. Removal of heavy metals from waters by means of natural zeolites. Water. Res., 1984, 18, 1501-1507.

[75] Ho, Y.S. Review of second-order models for adsorption systems. $J$. Hazard. Matter, 2006, 136, 681-689.

[76] Hanif, M.A.; Nadeem, R.; Bhatti, H.N.; Ahmad, N.R.; Ansari, T.M. $\mathrm{Ni}(\mathrm{II})$ biosorption by Cassia fistula (Golden Shower) biomass. $J$. Hazard. Matter, 2007, 139, 345-355.

[77] Preetha, B.; Viruthagiri, T. Batch and continuous biosorption of chromium(VI) by Rhizopus arrhizus. Sep. Purif. Technol., 2007, 57, 126-133.

[78] Vijayaraghavan, K.; Palanivelu, K.; Velan, M. Biosorption of copper(II) and cobalt(II) from aqueous solutions by crab shell particles. Bioresource. Technol., 2006, 97, 1411-1419.

[79] Gokhale, S.V.; Jyoti, K.K.; Lele, S.S. Kinetic and equilibrium modeling of chromium (VI) biosorption on fresh and spent Spirulina platensis/Chlorella vulgaris biomass. Bioresource. Technol., 2008, 99, 3600-3608.

[80] Vijaya, Y.; Popuri, S.R.; Boddu, V.M.; Krishnaiah, A. Modified chitosan and calcium alginate biopolymer sorbents for removal 
of nickel (II) through adsorption. Carbohyder. Polym., 2008, 72, 261-271.

[81] Akhtar, N.; Iqbal, M.; Zafar, SI.; Iqbal, J. Biosorption characteristics of unicellular green alga Chlorella sorokiniana immobilized in loofa sponge for removal of $\mathrm{Cr}(\mathrm{III})$. J. Environ. Sci., 2008, 20, 231-239.

[82] Malkoc, E.; Nuhoglu, Y. Investigations of nickel(II) removal from aqueous solutions using tea factory waste. J. Hazard. Matter, 2005, 127, 120-128.

[83] Pino, G.H.; Souza de Mesquita, L.M.; Torem, M.L.; Saavedra Pinto, G.A. Biosorption of cadmium by green coconut shell powder. Miner. Eng., 2006, 19, 380-387.

[84] Nadeem, R.; Hanif, M.A.; Shaheen, F.; et al. Physical and chemical modification of distillery sludge for $\mathrm{Pb}(\mathrm{II})$ biosorption. J. Hazard. Matter, 2008, 150, 335-342.

[85] Schiewer, S.; Patil, S.B. Pectin-rich fruit wastes as biosorbents for heavy metal removal: Equilibrium and kinetics. Bioresource. Technol., 2008, 99, 1896-1903.

[86] Namasivayam, C.; Sureshkumar, M.V. Removal of chromium(VI) from water and wastewater using surfactant modified coconut coir pith as a biosorbent. Bioresource. Technol., 2008, 99, 2218-25.

[87] Isik, M. Biosorption of Ni(II) from aqueous solutions by living and non-living ureolytic mixed culture. Colloid. Surf. B: Biointerf., 2008, 62, 97-104

[88] Dundar, M.; Nuhoglu, C.; Nuhoglu, Y. Biosorption of Cu(II) ions onto the litter of natural trembling poplar forest. J. Hazard. Mat., 2008, 151, 86-95.

[89] AydIn, H.; Bulut, Y.;Yerlikaya Ç. Removal of copper (II) from aqueous solution by adsorption onto low-cost adsorbents. $J$. Environ. Manage., 2008, 87, 37-45.

[90] Zafar, M.N.; Nadeem, R.; Hanif, M.A. Biosorption of nickel from protonated rice bran. J. Hazard. Mat., 2007, 143, 478-485.

[91] Gupta, V.K.; Rastogi, A. Biosorption of lead from aqueous solutions by green algae Spirogyra species: Kinetics and equilibrium studies. J. Hazard. Matter, 2008, 152, 407-414.

[92] Dahiya, S.; Tripathi, R.M.; Hegde, A.G. Biosorption of heavy metals and radionuclide from aqueous solutions by pre-treated arca shell biomass. J. Hazard Matter, 2008, 150, 376-386.

[93] Vilar, V.J.P.; Botelho, C.M.S.; Boaventura, R.A.R. Copper removal by algae Gelidium, agar extraction algal waste and granulated algal waste: Kinetics and equilibrium. Bioresource. Technol., 2008, 99, 750-762.

[94] Padmavathy, V. Biosorption of nickel(II) ions by baker's yeast: Kinetic, thermodynamic and desorption studies. Bioresource. Technol., 2008, 99, 3100-3109.

[95] Djeribi, R.; Hamdaoui, O. Sorption of copper(II) from aqueous solutions by cedar sawdust and crushed brick. Desalination., 2008, 225, 95-112.

[96] Apiratikul, R.; Pavasant, P. Batch and column studies of biosorption of heavy metals by Caulerpa lentillifera. Bioresource. Technol., 2008, 99, 2766-2777.

[97] Baral, S.S.; Das, S.N.; Rath, P. Hexavalent chromium removal from aqueous solution by adsorption on treated sawdust. Biochem. Eng. J., 2006, 31, 216-222.

[98] Mohan, D.; Chander, S. Single, binary, and multicomponent sorption of iron and manganese on lignite. J. Colloid. Interface Sci., 2006, 299, 76-87.

[99] Tertre, E.; Berger, G.; Castet, S.; Loubet, M.; Giffaut, E. Experimental sorption of $\mathrm{Ni}^{2+}, \mathrm{Cs}^{+}$and $\mathrm{Ln}^{3+}$ onto a montmorillonite up to $150{ }^{\circ}$ C. Geochim. Cosmochim. Acta., 2005, 69, 4937-4948.

[100] Zhang, L.; Huang, T.; Zhang, M.; Guo, X.; Yuan, Z. Studies on the capability and behavior of adsorption of thallium on nano- $\mathrm{Al}_{2} \mathrm{O}_{3}$. J. Hazard. Matter, 2008, 157, 352-357.

[101] Yavuz, Ö.; Altunkaynak, Y.; Güzel, F. Removal of copper, nickel, cobalt and manganese from aqueous solution by kaolinite. Water. Res., 2003, 37, 948-952.

[102] Echeverría, J.; Indurain, J.; Churio, E.; Garrido, J. Simultaneous effect of $\mathrm{pH}$, temperature, ionic strength, and initial concentration on the retention of Ni on illite. Colloid. Surf. A: Physicochem. Eng. Aspects., 2003, 218, 175-187.

[103] Entezari, M.H.; Soltani, T. Simultaneous removal of copper and lead ions from a binary solution by sono-sorption process. $J$. Hazard. Matter, 2008, 160, 88-93.

[104] Liu, R.; Ma, W.; Jia, C.Y.; Wang, L.; Li, H.Y. Effect of pH on biosorption of boron onto cotton cellulose. Desalination., 2007, 207, 257-267.
[105] Pavasant, P.; Apiratikul, R.; Sungkhum, V.; et al. Biosorption of $\mathrm{Cu}^{2+}, \mathrm{Cd}^{2+}, \mathrm{Pb}^{2+}$, and $\mathrm{Zn}^{2+}$ using dried marine green macroalga Caulerpa lentillifera. Bioresource. Technol., 2006, 97, 2321-2329.

[106] Dursun, A.Y. A comparative study on determination of the equilibrium, kinetic and thermodynamic parameters of biosorption of copper(II) and lead(II) ions onto pretreated Aspergillus niger. Biochem. Eng. J., 2006, 28, 187-195.

[107] Green-Ruiz, C.; Rodriguez-Tirado, V.; Gomez-Gil, B. Cadmium and zinc removal from aqueous solutions by Bacillus jeotgali: $\mathrm{pH}$, salinity and temperature effects. Bioresource. Technol., 2008, 99 , 3864-3870.

[108] Ho, Y.S.; Ofomaja, A.E. Biosorption thermodynamics of cadmium on coconut copra meal as biosorbent. Biochem. Eng. J., 2006, 30 , 117-123.

[109] Vijayaraghavan, K.; Padmesh, T.V.N.; Palanivelu, K.; Velan, M. Biosorption of nickel(II) ions onto Sargassum wightii: Application of two-parameter and three-parameter isotherm models. J. Hazard. Matter, 2006, 133, 304-308.

[110] Senthilkumar, R.; Vijayaraghavan, K.; Thilakavathi, M.; Iyer, P.V.R.; Velan, M. Application of seaweeds for the removal of lead from aqueous solution. Biochem. Eng. J., 2007, 33, 211-16.

[111] Chang, P.H.; Li, Z.; Yu, T.L.; Munkhbayer, S.; Kuo, T.S.; Huang, Y.C.; Jean, J.S.; Lin, H.K. Sorptive removal of tetracycline from water by palygorskite. J. Hazard. Matter., 2009, 165, 148-155.

[112] Partey, F.; Norman, D.I.; Ndur, S.; Nartey, R. Mechanism of arsenic sorption onto laterite iron concretions. Colloid. Surf. A: Physicochem. Eng. Aspects., 2009, 337, 164-172.

[113] Lee, S.; Anderson, P.R. EXAFS study of Zn sorption mechanisms on hydrous ferric oxide over extended reaction time. J. Colloid. Interface Sci., 2005, 286, 82-89.

[114] Cerjan Stefanovic, S.; Zabukovec Logar, N.; Margeta, K.; et al. Structural investigation of $\mathrm{Zn} 2+$ sorption on clinoptilolite tuff from the Vranjska Banja deposit in Serbia. Micropor. Mesopor. Mat., 2007, 105, 251-259.

[115] Donia, A.M.; Atia, A.A.; Al-amrani, W.A.; El-Nahas, A.M. Effect of structural properties of acid dyes on their adsorption behaviour from aqueous solutions by amine modified silica. J. Hazard. Matter, 2009, 161, 1544-1550.

[116] Demirbas, A. Agricultural based activated carbons for the removal of dyes from aqueous solutions: A review. J. Hazard. Matter., 2009, 167, 1-9.

[117] Lin, K.; Pan, J.; Chen, Y.; Cheng, R.; Xu, X. Study the adsorption of phenol from aqueous solution on hydroxyapatite nanopowders. J. Hazard. Matter, 2009, 161, 231-240.

[118] Martínez-Villegas, N.; Flores-Vélez, L.M.; Domínguez, O. Sorption of lead in soil as a function of $\mathrm{pH}$ : a study case in México. Chemosphere., 2004, 57, 1537-1542.

[119] Xu, H.; Yang, L.; Wang, P.; Liu, Y.; Peng, M. Kinetic research on the sorption of aqueous lead by synthetic carbonate hydroxyapatite. J. Environ. Manage., 2008, 86, 319-328.

[120] Small, T.D.; Warren, L.A.; Ferris, F.G. Influence of ionic strength on strontium sorption to bacteria, Fe(III) oxide, and composite bacteria-Fe(III) oxide surfaces. Appl. Geochem., 2001, 16, 939-946.

[121] Coppin, F.; Berger, G.; Bauer, A.; Castet, S.; Loubet, M. Sorption of lanthanides on smectite and kaolinite. Chem. Geol., 2002, 182, 57-68.

[122] El Aamrani, F.Z.; Duro, L.; de Pablo, J.; Bruno, J. Experimental study and modeling of the sorption of uranium(VI) onto olivinerock. Appl. Geochem., 2002, 17, 399-408.

[123] Korichi, S.; Bensmaili, A. Sorption of uranium (VI) on homoionic sodium smectite experimental study and surface complexation modeling. J. Hazard. Matter, 2009, 169, 780-793.

[124] Bradbury, M.H.; Baeyens, B. Sorption of $\mathrm{Eu}$ on $\mathrm{Na}-$ and $\mathrm{Ca}-$ montmorillonites: experimental investigations and modelling with cation exchange and surface complexation. Geochim. Cosmochim. Acta., 2002, 66, 2325-2334.

[125] Serrano, S.; O'Day, P.A.; Vlassopoulos, D.; García-González, M.T.; Garrido, F. A surface complexation and ion exchange model of $\mathrm{Pb}$ and $\mathrm{Cd}$ competitive sorption on natural soils. Geochim. Cosmochim. Acta., 2009, 73, 543-558.

[126] Heidmann, I.; Christl, I.; Leu, C.; Kretzschmar, R. Competitive sorption of protons and metal cations onto kaolinite: experiments and modeling. J. Colloid. Interface Sci., 2005, 282, 270-282.

[127] Missana, T.; Garcia-Gutierrez, M.; Alonso, U. Sorption of strontium onto illite/smectite mixed clays. Physics and Chemistry of the Earth, Parts A/B/C. 2008, 33(Supplement 1), S156-S62. 
[128] Pehlivan, E.; Özkan, A.M.; Dinç, S.; Parlayici, Ş. Adsorption of $\mathrm{Cu}^{2+}$ and $\mathrm{Pb}^{2+}$ ion on dolomite powder. J. Hazard. Matter., 2009, $167,1044-1049$

[129] Tan, X.; Fan, Q.; Wang, X.; Grambow, B. Eu(III) Sorption to $\mathrm{TiO}_{2}$ (Anatase and Rutile): Batch, XPS, and EXAFS Studies. Environ. Sci. Technol., 2009, 43, 3115-3121.

[130] Jiang, M.; Wang, Q.; Jin, X.; Chen, Z. Removal of Pb(II) from aqueous solution using modified and unmodified kaolinite clay. $J$. Hazard. Mat., 2009, 170, 332-339.

[131] Monvisade, P.; Siriphannon, P. Chitosan intercalated montmorillonite: Preparation, characterization and cationic dye adsorption. Appl. Clay. Sci., 2009, 42, 427-431.

[132] Pereira, M.F.R.; Soares, S.F.; Órfäo, J.J.M.; Figueiredo, J.L. Adsorption of dyes on activated carbons: influence of surface chemical groups. Carbon., 2003, 41, 811-821.

[133] Özdemir, G.; Yapar, S. Adsorption and desorption behavior of copper ions on Na-montmorillonite: Effect of rhamnolipids and $\mathrm{pH}$. J. Hazard. Mat., 2009, 166, 1307-1313.

[134] Saha, B.; Tai, M.H.; Streat, M. Metal Sorption Performance of an Activated Carbon After Oxidation and Subsequent Treatment. Process. Saf. Environ. Protect., 2001, 79, 345-351.

[135] Ramesh, A.; Hasegawa, H.; Maki, T.; Ueda, K. Adsorption of inorganic and organic arsenic from aqueous solutions by polymeric A1/Fe modified montmorillonite. Sep. Purif. Technol., 2007, 56, 90-100.

[136] Karagunduz, A.; Kaya, Y.; Keskinler, B.; Oncel, S. Influence of surfactant entrapment to dried alginate beads on sorption and removal of $\mathrm{Cu}^{2+}$ ions. J. Hazard. Matter, 2006, 131, 79-83.
[137] Wingenfelder, U.; Furrer, G.; Schulin, R. Sorption of antimonate by HDTMA-modified zeolite. Micropor. Mesopor. Mat., 2006, 95, 265-271.

[138] Nadeem, M.; Shabbir, M.; Abdullah, M.A.; Shah, S.S.; McKay, G. Sorption of cadmium from aqueous solution by surfactant-modified carbon adsorbents. Chem. Eng. J., 2009, 148, 365-370.

[139] Heidmann, I.; Christl, I.; Kretzschmar, R. Sorption of $\mathrm{Cu}$ and $\mathrm{Pb}$ to kaolinite-fulvic acid colloids: Assessment of sorbent interactions. Geochim. Cosmochim. Acta., 2005, 69, 1675-1686.

[140] Li, A.; Dai, J. Effects of fulvic fractions on the pH-dependent sorption of $\mathrm{Cu}$ (II) to kaolinite. Water. Res., 2006, 40, 1951-1956.

[141] Entezari, M.H.; Sharif, Al-Hoseini, Z. Sono-sorption as a new method for the removal of methylene blue from aqueous solution. Ultrasonics. Sonochem., 2007, 14, 599-604.

[142] Entezari, M.H.; Bastami, T.R. Influence of ultrasound on cadmium ion removal by sorption process. Ultrasonics. Sonochem., 2008, 15 , 428-432.

[143] Tan, X.L.; Wang, X.K.; Geckeis, H.; Rabung, Th. Sorption of $\mathrm{Eu}(\mathrm{III})$ on humic acid or fulvic acid bound to alumina studied by SEM-EDS, XPS, TRLFS and batch techniques. Environ. Sci. Technol., 2008, 42, 6532-6537.

[144] Fan, Q.H.; Tan, X.L.; Li, J.X.; Wang, X.K.; Wu, W.S.; Montavon, G. Sorption of $\mathrm{Eu}(\mathrm{III})$ on Attapulgite Studied by Batch, XPS and EXAFS Techniques. Environ. Sci. Technol., 2009, 43, 57765782.

(C) Zhao et al.; Licensee Bentham Open.

This is an open access article licensed under the terms of the Creative Commons Attribution Non-Commercial License (http://creativecommons.org/licenses/by-nc/3.0/) which permits unrestricted, non-commercial use, distribution and reproduction in any medium, provided the work is properly cited. 